\title{
Titanium dioxide as a Catalyst for Photodegradation of Various Concentrations of Methyl Orange and Methyl Red dyes using Hg Vapour Lamp with Constant pH
}

\author{
A. KISTAN ${ }^{1,2 *}$, V. KANCHANA ${ }^{3}$, L. SAKAYASHEELA ${ }^{2}$, J. SUMATHI ${ }^{2}$, \\ A.PREMKUMAR ${ }^{2}$, A.SELVAM ${ }^{2}$ and THAMINUM ANSARI $A^{4}$ \\ ${ }^{1}$ Research and Development Centre, Bharathiar University at Coimbatore, India. \\ ${ }^{2}$ Panimalar Institute of Technology, Chennai-123, India. \\ ${ }^{3}$ Sree Sastha Institute of Engineering \& Technology, Chennai, India. \\ ${ }^{4}$ P.G. Research Department Muthurangam Government Arts College, Vellore, India. \\ ${ }^{*}$ Corresponding author E-mail: vishmikrish@gmail.com \\ http://dx.doi.org/10.13005/ojc/340250
}

(Received: January 01, 2017; Accepted: February 10, 2018)

\begin{abstract}
The photo-catalytic activity of $\mathrm{TiO}_{2}$ catalyst is very much useful to removal of color from dye industry effluent from tanneries, textile industry, and Ink factory. The Novelty of this study, we have found on a very simple method to compare the photocatalytic activity of titanium dioxide for the different concentration of two different Organic dyes (Methyl Orange and Methyl Red) which were not compared in the past studies. This method can be carried out in a normal chemical laboratory. and easy way with limited use of chemicals and simple lab equipment's. Dye solutions having pigments with high photocatalytic activity lose their color within several minutes of UV-Visible radiation exposure (optical windows 160W (Hg lamp medium pressure)) whereas, dye solutions having UV-stable $\mathrm{TiO}_{2}$ would not degrade within several hours of radiation exposure. For both dyes the color started fading quickly when the light radiation was passed continuously for a long time (15 to 120 minutes).It was also found that concentration of both dyes decreased, with time or the degradation increased. The effect of varying the dye concentration increases with degradation rate decreases. The rate constant value undergoes a marginal decreases at $\mathrm{pH}=4.2$ when the Methyl Orange dye concentration was increased. The degradation measurements were carried out using Shimadzu UV-Visible 1601 spectrometer in the photon energy range of wave length 200 to $700 \mathrm{~nm}$ aid of glass cell (made of Quartz) with $10 \mathrm{~mm}$ optical path length.
\end{abstract}

Keywords: Organic dyes, Hg lamp, pH, Methyl Orange (MO), Methyl Red (MR), Degradation. 


\section{INTRODUCTION}

\section{Water pollution by tanneries, Textile and dye industries}

More than thirty thousand trading dyes founded. According to more than eighty thousands various chemical structures are utilized in industries such as textile, tanneries, food pharmaceutical, paper and ink industries and used dyes are normally discharged in waste water ${ }^{3}$. The effluent containing these dyes are normally removed by physical, oxidative or common method called as sludge process. Above mentioned process has a various draw backs and its produce secondary pollution due to utilizations of chemicals and its accumulated in species creates bio-resistant in the environment. Both textile and tanneries are very highest (more $50 \%$ ) user of dyes. Utilizing dyes in wide range of supporting reagents for different coloring skins, dyeing, cleaning leathers, printing and finishing procedure. Mill effluents, Fiber class or irrespective of dyes are extremely colored by unabsorbed dyes were varied due to the dye-fiber system.

In textile industry Azo-dyes are normally used and create the various environmental issues. In general waste water produced from various industrials includes tanneries, food and pharmaceuticals, and ink industries are utilizing dyes for various purposes, which requires proper treatments afore it is released to the surrounding. In addition, effluent streams released from tanneries and textile industry consists of toxic or carcinogenic substances along with their by-products. Recently, treatments are more concentrated not only to elucidate the environment impact but also suggest that dyes can be reused.

\section{Treatment of polluted water}

From the environmental perspective, the elimination of synthetic dyes is one of the great concerns, because degradation of dye and dye byproducts are also may be carcinogenic so treatment cannot fully dependents upon the biodegradation alone. Henceforth, decolonization of dye house effluent by elimination of dyes has become a very essential need in waste water treatments, tanneries and textile industry ${ }^{2}$. The environment concerns about use of dye in effluent ongoing problem for dye stuff productions, dyers and water industries.
The problem of color in waste water is common in many Tanneries and dyes houses. Hence, significant increase in standards of stringent color is enforced by common bodies to decrease the amount of effluent and water courses. Many methods are employed to treat waste water containing organic dyes and pigment such as adsorption, sedimentation, flocculation, floatation, reverse osmosis, fractionation etc., but the treatment of dye containing waste water containing dye by the above conventional methods has various limitation due to the significant increase in the refractory materials originated in waste water effluents, complications in the elimination of color and expensiveness. Elimination of organic nonbiodegradable chemicals is an essential ecological problem. Dyes are main class of synthetic organic compounds utilized in the textile industry as well as its also common industrial pollutants, due to modern dyes stability, management of biological treatments techniques for industrial waste water are ineffective resulting often in an intensively colored release from the treatment facilities ${ }^{5-8}$. The above problems could be overcome by the 'photocatalytic method' which is widely employed in complete degradation process. The direct photocatalytic reaction by using semiconductor powders has been shown to effectively degrade many kinds of pollutants.

\section{Photodegradation}

Photodegradation is degradation of molecules caused by the absorption of UV-Visible radiation i.e., the dissociation of molecules into smaller pieces. There are also irreversible structural changes such as the denaturing of proteins, and the addition of other atoms or molecules. A common Photodegradation reaction is photo-oxidation ${ }^{10}$. This type of Photodegradation is used by some drinking water facilities to destroy pollutants. Photodegradation in the environment is part of the process by which ambergris evolves from its fatty precursor. Photosensitized degradation of colored contamination in waste water on semiconductor surface is of current importance ${ }^{10-14}$. Although semiconducting $\mathrm{TiO}_{2}$ in presence of $\mathrm{UV}$ radiation has become the bench mark photo-catalyst for degradation of myriad or a water bound ${ }^{15-18}$ pollutants as documental in the literature, the vital drawback of $\mathrm{TiO}_{2}$ semiconductor is that it absorbs a small portion of solar spectrum in the UV region 
(band gap energy of $\mathrm{TiO}_{2}$ is 3.0 to $3.2 \mathrm{eV}$ ). hence the photo-catalytic process has the disadvantage that it cannot harvests maximum solar energy by utilizing visible light. A large number of dyes stuff material so with intense color and toxicity introduced into the aquatic systems, are resistant to degradation. More recently the degradation of colored ones in environmental protection studies has gained importance. Azo dyes are typical class of organic pigments and they are represented as toxic compounds. Method of decolorizing dye effluents has been gaining attention. An inherent advantage of heterogeneous or homogenous photo catalysis emerges when solar irradiation is used as a photon source ${ }^{19}$.

\section{Titanium dioxide as photocatalyst}

$\mathrm{TiO}_{2}$ semiconductor is a very good Photocatalyst for the elimination of pollutants from air and water due to its low cost, chemical stability, no toxicity, high photocatalytic reactivity and insolubility. A further important advantage is the fact that the process can be powered by solar energy ${ }^{20,21}$, thus reducing significantly the electrical power requirements and operational costs. It should be noted that with visible light, the Photodegradation processes by different routes, involving for example electron transfer from the excited sate of the dye molecules adsorbed on the $\mathrm{TiO}_{2}$ surface into the conduction band of $\mathrm{TiO}_{2}$ are possible but such process are less efficient than those occurring with UV light ${ }^{4}$.For the photocatalytic oxidation $\left(\left(\mathrm{TiO}_{2} / \mathrm{UV}\right)\right)$, the semiconductor absorbs UV light and hydroxide Radicals are generated mainly from the absorbed water and hydroxide ions. The mechanism of the $\mathrm{TiO}_{2} / \mathrm{UV}$ degradation has been described using the band-gap model ${ }^{22}$. It is well established that by irradiation of an aqueous $\mathrm{TiO}_{2}$ suspension with light energy greater than the band gap energy of the semiconductor, conduction band electrons and valence band holes are generated $^{23}$. These will act as strong oxidizing agents that can easily attack any organic molecules and adsorbed on, or located close to the surface catalyst, thus leading to their complete degradation into small inorganic species.

$\mathrm{TiO}_{2}+\mathrm{hv}=====>\mathrm{TiO}_{2}\left(\mathrm{~h}^{+}+\mathrm{e}^{-}\right)(\mathrm{hve} \geq \mathrm{Eg}=3.2 \mathrm{eV}$; $\lambda=390 \mathrm{~nm})$

$\mathrm{O}_{2}+\mathrm{e}^{-}=====>\mathrm{O}^{2-}$

$\mathrm{H}_{2} \mathrm{O}+\mathrm{h}^{+}=====>\mathrm{H}^{+}+\mathrm{OH}^{*}$

$\mathrm{OH}^{*}+\mathrm{RH}=====>\mathrm{H}_{2} \mathrm{O}+\mathrm{R}^{*}$

$\mathrm{R}+\mathrm{O}_{2}=====>\mathrm{ROO}^{2}=====>=====>\mathrm{CO}_{2}+$ Other products

\section{Earlier work of photodegradation}

The photo-assisted degradation of erythrosine and Rhodamine $B$ has been investigated in an aqueous $\mathrm{TiO}_{2}$ dispersion under irradiation by visible light ${ }^{24}$. Wang investigated ${ }^{25}$ the photocatalytic degradation of eight commercial dyes including $\mathrm{MO}$ using $\mathrm{TiO}_{2}$ suspension under solar light. The possibility of using solar irradiation for detoxification of $\mathrm{MO}$ as a model compound was also explored by other workers ${ }^{26}$. Wang ${ }^{27}$ prepared and investigated the photocatalytic activity of $\mathrm{ZnO} / \mathrm{TiO}_{2} / \mathrm{SnO}_{2}$ mixture for decolonization of MO under UV light and found that this mixture was photocatalytically more active than $\mathrm{TiO}_{2}$ and $\mathrm{SnO}_{2}$ but slightly less active $\mathrm{ZnO}^{28-30}$. In recent years, the Photo catalyzed oxidation kinetics of acid blue-40 at different $\mathrm{pH}$ Values by $\mathrm{TiO}_{2} / \mathrm{UV}$ were studied ${ }^{32}$. It is found that $\mathrm{pH}=3$, photocatalytic Oxidation kinetics of Acid blue40 follows the Longmuir Hinshelwood Model with reaction rate constant $(\mathrm{k})$ of $0.0074 \mathrm{~m} / \mathrm{min}$. It is found that ferrous ion does not have significant influence on the reaction while $\mathrm{H}_{2} \mathrm{O}_{2}$ could retard the reaction when its concentration is higher than $0.01 \mathrm{~nm}$. Photodegradation of series of dyes (Rhodamine B, Orange II, Alizarin red and Eosin) in the presence of $\mathrm{TiO}_{2}$ particles under visible light irradiation led to formation of $\mathrm{H}_{2} \mathrm{O}_{2} \cdot \mathrm{H}_{2} \mathrm{O}_{2}$ was detected because its formation rate was greater than decomposition rate $^{33}$. Photocatalytic decolorization and degradation of an Azo dye Reactive orange4 with $\mathrm{TiO}_{2}$ / P-25(Degussa) as Photocatalyst is examined. The effect of various parameters such as catalyst loading, $\mathrm{pH}$ and initial concentration of the dye has been examined ${ }^{35}$.

The degradation was strongly enhanced in the presence of electron acceptors such as $\mathrm{H}_{2} \mathrm{O}_{2}$, $\left(\mathrm{NH}_{4}\right)_{2} \mathrm{~S}_{2} \mathrm{O}_{8}$ and $\mathrm{KBrO}_{3}{ }^{35}$. The photocatalytic decolorization of reactive Blue19 (RB-19) ${ }^{34-38}$. In aqueous solutions containing $\mathrm{TiO}_{2}$ or $\mathrm{ZnO}$ as catalyst and concluded that $\mathrm{ZnO}$ is more efficient catalyst that $\mathrm{TiO}_{2}$ in the color removal of $\mathrm{RB}$ of $\mathrm{RB}$ $19^{39}$.The degradation rates were compared with disappearance and elimination rates. In this photo catalytically Degradation of Azo dye, the disappearance proceeds through both Oxidation and reduction ${ }^{41}$.Photo catalytically degradation of Methylene blue a cationic dye and procion red, an anionic dye has been examined under $\mathrm{TiO}_{2} \mathrm{pH}$ dependent because of its amphoteric nature. It has been found that 
$\mathrm{pH}-9.5$ and $\mathrm{pH}-3.5$ are suitable for Methylene blue and procion red respectively ${ }^{42}$. The degradation of biological dyes such as Methylene blue and Malachite green 7 was carried out with Nano $\mathrm{TiO}_{2}$ which have a particle size of $16-17 \mathrm{~nm}$. The absorption peak of Methylene blue decreases Photocatalyst time ${ }^{43}$.

Desensitization, a method according for degradation of colorants in actinic radiation welllighted dye changed $\mathrm{TiO}_{2}$ dispersion, might even be possible for degradation of colorless lake water pollutants ${ }^{44,45}$. Recently a number and researchers have restricted heterogeneous photocatalytic decomposition of dye within the presence of ultraviolet illumination or visible light ${ }^{46}$.

$$
\begin{aligned}
& \mathrm{TiO}_{2}+\mathrm{hv}=====>\mathrm{h}^{+}(\mathrm{VB})+\mathrm{e}^{-}(\mathrm{CB}) \\
& \mathrm{h}^{+}(\mathrm{VB})+\mathrm{OH}^{-}(\text {water })=====>\mathrm{OH}^{*}(\text { ads }) \\
& \mathrm{H}_{2} \mathrm{O}(\text { ads })+\mathrm{h}^{+}(\mathrm{VB})=====>\mathrm{OH}^{*} \text { (ads) }+\mathrm{H}^{*} \text { (ads) } \\
& \text { Dye }+\mathrm{OH}^{*} \text { (ads) =====> Degradation of the dye. }
\end{aligned}
$$

Desensitization, a method according for degradation of colorants in actinic radiation welllighted dye changed $\mathrm{TiO}_{2}$ dispersion, might even be possible for degradation of colorless lake water pollutants ${ }^{44,45}$. Recently a number and researchers have restricted heterogeneous photocatalytic decomposition of dye within the presence of ultraviolet illumination or visible light 46 . Aerophilous method has been additionally accustomed decolorize and mineralize several styles of group dyes in a very bench scale by exploitation each artificial irradiation ${ }^{47,48}$ and star technology, industrial dyes in $\mathrm{TiO}_{2}$ suspension underneath star lightweight however the set of equipment employed by wang ${ }^{48-50}$ were regardful and concentration of the dye resolution was totally different in comparison to the current work.

Novelty of in this present studies: we have found on a very simple method to compare the photocatalytic activity of $\mathrm{TiO}_{2}$ for different Concentration of two different Organic dyes (Methyl Orange and Methyl Red) which were not compared in the past studies. This experiment was done in a normal chemical lab and easy way with limited use of chemicals and simple lab equipment's. For both dyes, Methyl Orange and Methyl Red dyes the color started fading quickly when the light radiation was passed continuously for a long time (120 minutes).
It has been observed that concentration of both dyes decreased, with time or the degradation increased. The effect of varying the dye concentration increases with degradation rate decreases. The rate constant value undergoes marginal decreases at $\mathrm{pH}=4.2$ when the methyl orange dye concentration was increased. The rate constant value undergoes a marginal decreases at $\mathrm{pH}=4.5$ when the methyl orange dye concentration was increased. From these researches it has been observed that degradation of methyl red organic dye (MR) dye slightly faster than degradation of methyl orange dye (MO) which was not studied in the previous similar works.

The present work deals with photocatalytic ( $\mathrm{TiO}_{2} / \mathrm{hv}$ ) degradation for color removal from solution containing acid-base indicator, Methyl Orange and alkyl Red, Methyl Red dyes. Mercury $(\mathrm{Hg})$ vapour lamps were used as irradiation sources. Utilization of daylight because the ultraviolet radiation energy supply is useful from ecological purpose of read. The dependence of dye icon oxidization rate on the subsequent parameters: Initial dye concentration, irradiation time, irradiation intensity were additionally investigated.

\section{Scope of the investigation}

The removal of artificial dyes in effluent water from workplace industries, dye industries, textile industries etc., is of nice concern since a number of the dyes and its degradation products are harmful to human life. Therefore degradation of dyes becomes a crucial facet within the treatment of waste water. Several strategies are used for the dye degradation method however the photocatalytic degradation method' as wide used for the entire degradation method chiefly thanks to economic practicability and also the easier nature of the technique concerned. Much attention has been centered within the past two decade on the photocatalytic degradation of organic pollutants mediate by $\mathrm{TiO}_{2}$ particles in liquid dispersion irradiated by ultraviolet radiation and visual light ${ }^{32}$.

The big body of proof that has been collected suggests that this technique is beyond any doubt a possible and effective approach towards the degradation of big variety harmful organic pollutants in waste water and towards the purification of beverage. Therefore $\mathrm{TiO}_{2}$ is one the normally used environmental icon catalyst for the reaction of liquid organic pollutants and $\mathrm{TiO}_{2}$ catalyst exhibits smart activity for the icon reaction or chemical group dyes ${ }^{31}$. 
Structure of Methyl Orange (MO)

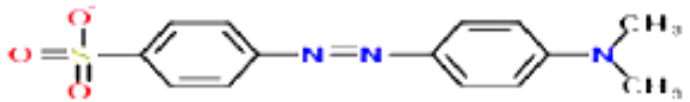

Structure of Methyl Red (MR)<smiles>CN(C)c1ccc(/N=N/c2ccccc2C(=O)O)cc1</smiles>

Visible light pathway

The mechanism of photocatalytic degradation of dye by visible light has been shown to be different from that of UV irradiation. In this process, the dye is excited by the visible light and not by semiconductor $\mathrm{TiO}_{2}$ is mixed with methyl orange and Methyl Red solution and magnetically stirred under visible light irradiation $(\lambda \max =365 \mathrm{~nm})$. The $\mathrm{TiO}_{2}$ particles are isolated from the solution and the change in the absorbance of organic methyl orange and organic methyl red dyes are monitored spectrometrically. The rate constant for the degradation kinetics is determined for

(i) Effect of dye concentration

(ii) $\%$ of degradation is evaluated.

\section{EXPERIMENTAL METHOD}

\section{(a). Preparation of methyl orange solution}

A stock solution $\left(1 \times 10^{-3} \mathrm{M}\right)$ of methyl orange was prepared by dissolving $0.032 \mathrm{~g}$ of methyl orange powder (A.R. Qualigens) in 100ml of deminineralised water.

\section{(b). Preparation of methyl red solution}

A stock solution $\left(1 \times 10^{-3} \mathrm{M}\right)$ of methyl red prepared by dissolving $0.28 \mathrm{~g}$ of methyl red powder (A.R. Qualigens) in $5 \mathrm{ml}$ and $95 \mathrm{ml}$ of demineralised water.

\section{Photo- reactor and light source}

The Photo-reactor used for the degradation method could be a cylindrical cell with optical windows 160w (Hg lamp medium pressure). The sunshine supply is $\mathrm{Hg}$ lamp medium pressure actinic ray culminated by lens. The setup was lined employing a cardboard box to make sure darkness throughout the passage of sunshine from the sunshine supply.

\section{Degradation experiments}

The aqueous $\mathrm{TiO}_{2}$ suspension was prepared by the addition of $30 \mathrm{mg}$ of Titanium dioxide (A.R.Qualigens) to a $50 \mathrm{ml}$ of aqueous dye solution, whose concentration is changed between $1 \times 10^{-5} \mathrm{~N}$ to $1 \times 10^{-4} \mathrm{~N}$. The suspension was magnetically stirred with irradiation within the dark for $1 \mathrm{hr}$ to confirm the institution of associate degree adsorption/ desorption equilibrium. The dispersions were unbroken underneath constant air equilibrated condition before and through the passage irradiation. At regular time intervals, $5 \mathrm{ml}$ of aliquots were collected and centrifuged to get rid of the $\mathrm{TiO}_{2}$ particulate. The unvaried solutions were collected and their sorption measured victimization Shimadzu UV-Visible 1601 spectroscope.

\section{Degradation kinetics}

The decrease in the absorbance of the Methyl Orange and Methyl red dye solutions are monitored by UV-Visible spectrometer at 460nm and $550 \mathrm{~nm}$ respectively. The decrease in absorbance is noted as function of time in minutes. The visible spectrum is recorded in the region of $300 \mathrm{~nm}$ to $700 \mathrm{~nm}$ both prior and after irradiation.

\section{Absorbance measurement}

The absorbance of dye goes to scientific method. Solutions before and when degradation were measured at completely different completely different\} degradation time and different irradiation sources. Measurements were meted out victimization Shimadzu UV-Visible 1601 spectroscope within the gauge boson energy vary of wave length three hundred to 700nm aid of glass cell(made of Quartz) with $10 \mathrm{~mm}$ optical path length. The percentage of degradation was calculated from the following equation:

$$
\text { Degradation } \%=1-\frac{\text { At }}{A o}
$$

Where $A_{t}$ is that the absorbance once time $t$ and $A_{0}$ is that the absorbance of initial concentration of dye before degradation.

\section{RESULT AND DISCUSSION}

\section{Study of photo degradation}

The degradation of the dye in aqueous solution occurs when it is irradiated with visible light (Fig. 1.c and 2.c) The photocatalytic degradation of 
Organic dyes of Methyl Orange and Methyl Red with Titanium dioxide catalyst obeys the first order reaction kinetics at all dye concentration and the rate expression is given by the equation.

$$
\frac{-d c}{d t}=\mathrm{k}^{1}[\mathrm{C}]
$$

Where $\mathrm{k}^{1}$ is the first order rate constant. The dye is adsorbed on to $\mathrm{TiO}_{2}$ surface and the adsorption-desorption equilibrium is reached within
30 minutes. The equilibrium constant of the dye solution is determined after this period and it is taken as the initial dye concentration for the kinetic analysis. Integrating the above equation (with the limit) $\mathrm{C}=\mathrm{C}_{0}$ and $\mathrm{t}=0$ with $\mathrm{C}_{0}$ being the equilibrium concentration of the bulk solution $\frac{\ln [c 0]}{[c]}=\mathrm{k}^{1} \mathrm{t}$, where $\mathrm{C}_{0}$ is the equilibrium concentration of dye and $\mathrm{C}$ is the concentration at time $t$ and $k^{1}$. The plot of log $(a-x)$ against Time follows the first order kinetics, and from this plot the rate constant is calculated.

Table.1(a): Kinetic plot of Visible/Titanium dioxide-Photocatalyzed degradation of Methyl Orange dye

Kinetic plot of Visible/ Titanium dioxide Photocatalyzed degradation of Methyl Orange dye

\begin{tabular}{lcccc}
\hline & Time(min.) & $\begin{array}{c}\text { \% of Degradation } \\
\text { (No unit) }\end{array}$ & $\begin{array}{c}\frac{\mathrm{a}}{\log (\mathrm{a}-\mathrm{x})} \\
\text { (No unit) }\end{array}$ & $\frac{\mathrm{C}}{\mathrm{C}_{0}}$ \\
(No unit)
\end{tabular}

Table1(b): Kinetic plot of Visible/Titanium dioxide -Photocatalyzed degradation of Methyl Orange dye

\begin{tabular}{|c|c|c|c|c|}
\hline & Time(min.) & $\begin{array}{c}\% \text { of Degradation } \\
\text { (No unit) }\end{array}$ & $\begin{array}{l}\operatorname{a} \frac{a}{(a-x)} \\
\text { (No unit) }\end{array}$ & $\frac{\mathrm{C}}{\mathrm{C}_{0}}$ \\
\hline \multicolumn{5}{|l|}{$[$ Dye $]=4 \times 10-5 \mathrm{~N}$} \\
\hline $\mathrm{pH}=4.2$ & 15 & 14.59 & 0.0678 & 0.8548 \\
\hline$\left[\mathrm{TiO}_{2}\right]=30 \mathrm{mg} / 50 \mathrm{ml}$ & 30 & 24.86 & 0.1235 & 0.7521 \\
\hline \multirow[t]{2}{*}{ Rate Constant $=2.4152 \times 10-4 \mathrm{~N}$} & 45 & 35.35 & 0.1889 & 0.6571 \\
\hline & 60 & 48.11 & 0.2853 & 0.5183 \\
\hline
\end{tabular}

Table1(c): Kinetic plot of Visible/Titanium dioxide Photo catalyzed degradation of Methyl Orange dye

\begin{tabular}{|c|c|c|c|c|}
\hline & & & $a$ & C \\
\hline$[$ Dye $]=5 \times 10-5 \mathrm{M}$ & Time(min.) & $\begin{array}{c}\% \text { of Degradation } \\
\text { (No unit) }\end{array}$ & $\begin{array}{l}\log \overline{(a-x)} \\
\text { (No unit) }\end{array}$ & $\begin{array}{c}\frac{\overline{C_{0}}}{\text { (No unit) }} \\
\text { (No }\end{array}$ \\
\hline $\mathrm{pH}=4.2$ & 15 & 20.08 & 0.0951 & 0.8017 \\
\hline$\left[\mathrm{TiO}_{2}\right]=30 \mathrm{mg} / 50 \mathrm{ml}$ & 30 & 37.58 & 0.2033 & 0.6262 \\
\hline \multirow[t]{2}{*}{ Rate Constant $=2.4152 \times 10-4 \mathrm{M}$} & 45 & 45.37 & 0.2611 & 0.5481 \\
\hline & 60 & 63.12 & 0.4322 & 0.3697 \\
\hline
\end{tabular}


Table1(d): Kinetic plot of Visible/TiO2 Photocatalyzed degradation of Methyl Orange dye

Kinetic plot of Visible/ TiO2 Photocatalyzed degradation of Methyl Orange

\begin{tabular}{lcccc}
\hline & Time(min.) & $\begin{array}{c}\text { \% of Degradation } \\
\text { (No unit) }\end{array}$ & $\begin{array}{c}\mathrm{a} \\
\text { (No unit) }\end{array}$ & $\begin{array}{c}\mathrm{C} \\
\mathrm{C}_{0} \\
\text { (No unit) }\end{array}$ \\
$\mathrm{pH}=4.2$ & & 20.76 & 0.1282 & 0.7071 \\
{$\left[\mathrm{TiO}_{2}\right]=30 \mathrm{mg} / 50 \mathrm{ml}$} & 15 & 38.31 & 0.2471 & 0.6004 \\
Rate Constant = 2.4152 X 10-4 N & 30 & 46.19 & 0.3667 & 0.5211 \\
& 60 & 63.74 & 0.4881 & 0.2446 \\
\hline
\end{tabular}

Table2(a): Kinetic plot of Visible/Titanium-dioxide Photocatalyzed degradation of Methyl Red dye

Kinetic plot of Visible/ Titanium dioxide Photocatalyzed degradation of Methyl Red dye

\begin{tabular}{lcccc}
\hline & Time $(m i n)$. & $\%$ of Degradation & $\begin{array}{c}\log \frac{\mathrm{C}}{(\mathrm{a}-\mathrm{x})} \\
\text { (No unit) }\end{array}$ & $\begin{array}{c}\frac{\mathrm{C}_{0}}{\text { (No unit) }} \\
\text { (No unit) }\end{array}$ \\
{$[\mathrm{Dye}]=4 \times 10^{-5} \mathrm{M}$} & & 5.26 & 0.0354 & 0.9215 \\
$\mathrm{pH}=4.2$ & 15 & 10.52 & 0.0795 & 0.8325 \\
{$\left[\mathrm{TiO}_{2}\right]=30 \mathrm{mg} / 50 \mathrm{ml}$} & 30 & 15.78 & 0.1136 & 0.7697 \\
Rate Constant = 2.4152 X $10^{-4} \mathrm{M}$ & 45 & 23.69 & 0.1622 & 0.5448 \\
\hline
\end{tabular}

Table 2(b): Kinetic plot of Visible/Titanium dioxide Photocatalyzed degradation of Organic Methyl dye

\begin{tabular}{|c|c|c|c|c|}
\hline & Time(min.) & $\begin{array}{c}\% \text { of Degradation } \\
\text { (No unit) }\end{array}$ & $\begin{array}{c}\frac{a}{\log (a-x)} \\
\text { (No unit) }\end{array}$ & $\frac{\mathrm{C}_{\mathrm{C}_{0}}}{\text { (No unit) }}$ \\
\hline \multicolumn{5}{|l|}{$[$ Dye $]=5 \times 10^{-5} \mathrm{M}$} \\
\hline $\mathrm{pH}=4.2$ & 15 & 7.88 & 0.0569 & 0.8761 \\
\hline$\left[\mathrm{TiO}_{2}\right]=30 \mathrm{mg} / 50 \mathrm{ml}$ & 30 & 16.77 & 0.1082 & 0.7792 \\
\hline \multirow[t]{2}{*}{ Rate Constant $=2.4152 \times 10^{-4} \mathrm{M}$} & 45 & 23.05 & 0.1661 & 0.6801 \\
\hline & 60 & 28.99 & 0.2332 & 0.5844 \\
\hline
\end{tabular}

Table 2(c): Kinetic plot of Visible/Titanium dioxide Photocatalyzed degradation of Methyl Red dye

Kinetic plot of Visible/ Titanium dioxide Photocatalyzed degradation of Methyl Red dye

\begin{tabular}{|c|c|c|c|c|}
\hline & Time(min.) & $\begin{array}{c}\% \text { of Degradation } \\
\text { (No unit) }\end{array}$ & $\begin{array}{l}\log \frac{a}{(a-x)} \\
\text { (No unit) }\end{array}$ & $\frac{\frac{\mathrm{C}}{\mathrm{C}_{0}}}{\text { (No unit) }}$ \\
\hline \multicolumn{5}{|l|}{$[$ Dye $]=6 \times 10^{-5} \mathrm{M}$} \\
\hline $\mathrm{pH}=4.2$ & 15 & 12.33 & 0.0232 & 0.9478 \\
\hline$\left[\mathrm{TiO}_{2}\right]=30 \mathrm{mg} / 50 \mathrm{ml}$ & 30 & 22.07 & 0.0482 & 0.8951 \\
\hline \multirow[t]{2}{*}{ Rate Constant $=2.4152 \times 10^{-4} \mathrm{M}$} & 45 & 31.81 & 0.074 & 0.8416 \\
\hline & 60 & 41.55 & 0.1169 & 0.7635 \\
\hline
\end{tabular}


1.a. TitlePlot of Time Vs $\log \{a /(a-x)\}$

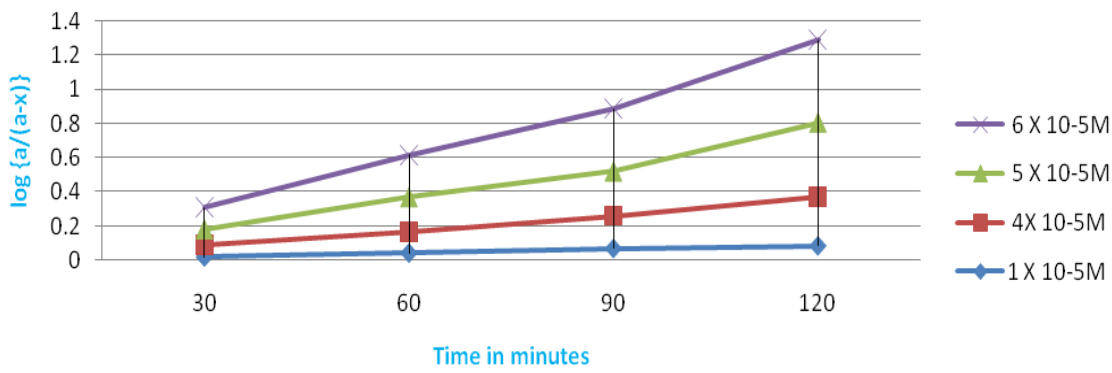

1.a. TitlePlot of Time Vs log $\{a /(a-x)\}$

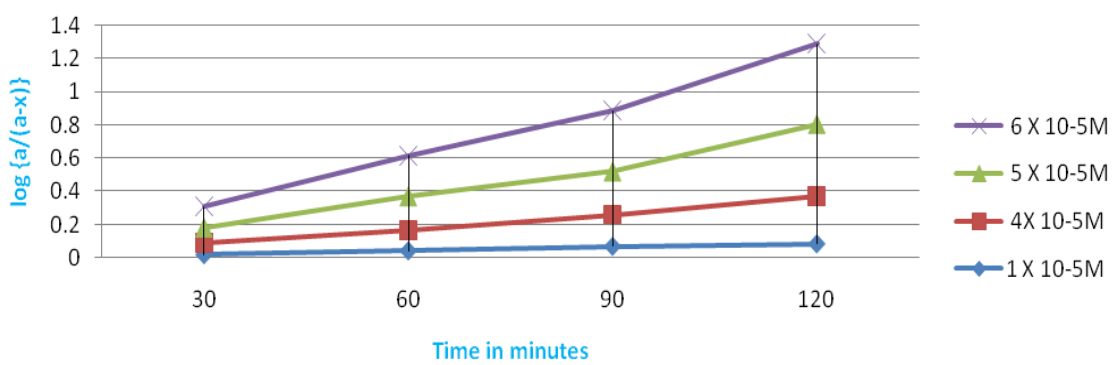

Graph. 1. Kinetic graphs of Visible / Titanium dioxide Photocatalysed degradation of Methyl Orange dye

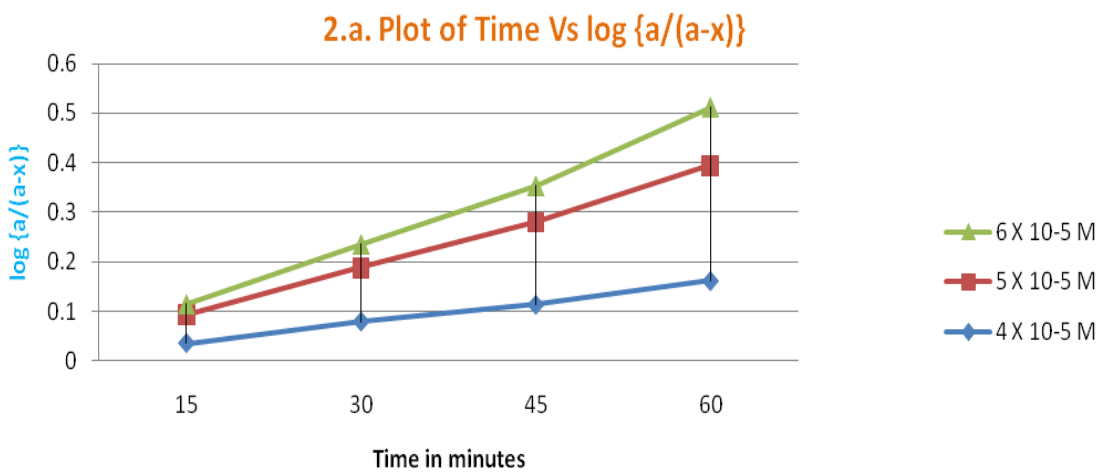

2.c.

2.b. Plot of Time Vs C / CO

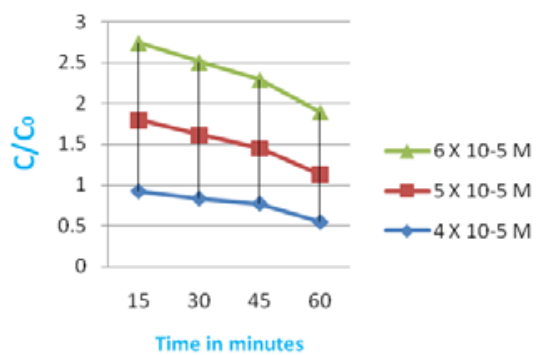

Plot of Time Vs \% of degradation

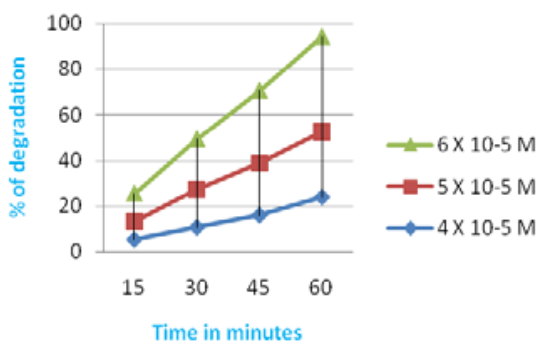

Graph. 2. Kinetic graphs of Visible / Titanium dioxide Photocatalysed degradation of Methyl Red dye (MR) 


\section{Effect of dye concentration}

The pollutant concentration is a variable parameter in wastewater treatment. The effect of various initial dye concentrations on the photocatalytic decolonization and degradation has been investigated with dye solution. The degradation rate constant for the Methyl Orange dye and Methyl Red dye under same $\mathrm{pH}$ and concentration values are shown in the table. 3 with respect to $\mathrm{pH}=4.2$, Temperature $=27^{\circ} \mathrm{C}$ and $\lambda_{\max }=$ $460 \mathrm{~nm}$ and $\mathrm{pH}=4.5$, Temperature $=27{ }^{\circ} \mathrm{C}$ and $\lambda_{\text {max }}=520 \mathrm{~nm}$.

Table 3: The rate of color degradation of Methyl Orange and Methyl Red dyes

\begin{tabular}{|c|c|c|c|c|}
\hline S.NO & [Dye] (M) & $\begin{array}{c}\text { [CATALYST] } \\
(\mathrm{mg}) / 50 \mathrm{ml}\end{array}$ & $\begin{array}{l}\text { Degradation of Methyl } \\
\text { Orange dye Rate constant } \\
\times 10^{-4} \mathrm{Sec}^{-1}(\mathrm{pH} \text { at } 4.2)\end{array}$ & $\begin{array}{l}\text { Degradation of Methyl Red } \\
\text { dye Rate constant } \times 10^{-4} \\
\operatorname{Sec}^{-1}(\mathrm{pH} \text { at } 4.5)\end{array}$ \\
\hline 1 & $1 \times 10^{-5}$ & 30 & 2.4152 & - \\
\hline 2 & $4 \times 10^{-5}$ & 30 & 1.2748 & 9.6282 \\
\hline 3 & $5 \times 10^{-5}$ & 30 & 1.2507 & 8.0551 \\
\hline 4 & $6 \times 10^{-5}$ & 30 & 0.8418 & 7.6653 \\
\hline
\end{tabular}

It determined that from higher than the Table.1, Table 2, Table 3, Graph1 and Graph 2 pair of shown the degradation rate constant decreases perpetually with [dye] concentration, degradation of different dyes ${ }^{[39,40,41}$. Thus, the time taken for the entire degradation of the dye is most for the dye of upper concentration and it's minimum for the dye of lower concentration. Once the dye concentration will increase, the number of dye absorbed on the chemical process surface will increase. This affects the chemical process activity of $\mathrm{TiO}_{2}$. The rise in dye concentration conjointly decreases the trail length of gauge boson getting in the dye solutions. At high dye concentration, a big quantity of lightweight ultraviolet illumination IUVI actinic radiation actinic ray\} light is also absorbed by the dye molecule instead of the catalyst and this might cut back the chemical process potency.

\section{Visible light pathway}

The mechanism of photocatalytic degradation of dye by visible light has been shown to be different from that of UV irradiation. In this process, the dye is excited by the visible light and not by semiconductor $\mathrm{TiO}_{2}$.

\section{Mechanism}

Initial of photocatalytic reaction

1. Dye $+\mathrm{hv} \rightarrow \mathrm{Dye}^{\star}$ (initiation)

2. $\mathrm{Dye}+\mathrm{TiO}_{2} \rightarrow \mathrm{Dye}^{*}+\mathrm{TiO}_{2}(\mathrm{e})$

3. $\mathrm{TiO}_{2}(\mathrm{e})+\mathrm{O}_{2} \rightarrow \mathrm{TiO}_{2}+\mathrm{O}^{2}-4 . \mathrm{TiO}_{2}(\mathrm{e})+\mathrm{O} 2+$ $2 \mathrm{H}^{+} \rightarrow \mathrm{H}_{2} \mathrm{O}_{2}$
5. $\mathrm{H}_{2} \mathrm{O}_{2}+\mathrm{TiO}_{2}(\mathrm{e}) \rightarrow \mathrm{OH}^{*}+\mathrm{OH}^{-}$
6. $\mathrm{Dye}^{*}+\mathrm{O}^{*}\left(\right.$ or $\mathrm{O}^{2-}$ or $\left.\mathrm{OH}^{*}\right) \rightarrow$ Peroxylated or hydroxylated intermediates

Subsequently, $\mathrm{TiO}_{2}$ plays the pivotal role of an electron and dye cation radials. The processes described by equations from 1 to 5 , example electron transfer, generation of peroxide radical anion, $\mathrm{H}_{2} \mathrm{O}_{2}$ and $\mathrm{OH}^{*}$ radical formation have been demonstrated earlier. In the present investigation the degradation of Methyl Orange and Methyl red with $\mathrm{TiO}_{2}$ catalyst is irradiated with visible light (ëmax $=365 \mathrm{~nm})$.

\section{Photo degradation of dyes by visible light}

The photolysis of the dye in aqueous solution is carried out by varying the following parameters;

Concentration of the dyes, 2. $\mathrm{pH}$, and the catalyst concentration is kept constant in all experiments.

The solution were irradiated with visible light $(\lambda \max =365 \mathrm{~nm})$ near UV light. The absorption peak ( $\lambda$ max for MO is $460 \mathrm{~nm}$, and ëmax for MR is $520 \mathrm{~nm}$ ) corresponding to the dye diminished and finally disappeared during photolysis, indicating the complete degradation of Methyl Orange. No new bands appeared in the visible region, corresponding to aromatic moieties and other similar intermediates. In the absence of UV light no significant degradation occurred prior to irradiation. Since the photo 
degradation of dye occurs predominantly on $\mathrm{TiO}_{2}$ surface the absorption of dyes molecule from aqueous solution on to $\mathrm{TiO}_{2}$ surface is very important. The extent of adsorption of dye at various concentrations in blank solution after the adsorption desorption equilibrium had been reached i.e. prior to UV irradiation. The absorbance of the solution prior to irradiation provides the initial concentration $\left(\mathrm{C}^{0}\right)$.

\section{Photocatalytic degradation mechanisms}

The complete assumption of dye catalyzed abasement advance that blind bandage holes $(\mathrm{h}+)$ and advice bandage electron(electrons-CB) are produced if aqueous $\mathrm{TiO}_{2}$ abeyance is apparent with ablaze activity $>$ than $(E g=3.2 \mathrm{eV})$ its bandage gap energy. The photon produced electrons can abatement the dye or acknowledge with electron can be abatement the dye or accompany with electron acceptors includes $\mathrm{O}_{2}$ captivated on the $\mathrm{Ti}(\mathrm{II})$ - apparent or attenuated in baptize abbreviating it to superoxide abolitionist anion $\mathrm{O}^{2}$. The photo produced holes can burn the amoebic atom to anatomy $\mathrm{R}^{\star}$, or added awful oxidant breed (Peroxide radicals) they are appear to be amenable for the heterogeneous. $\mathrm{TiO}_{2}$ photo atomization of amoebic substrate as dyes. Based on this adapted action in the semiconductor exoteric creates the abasement of dyes can be represented as follows.

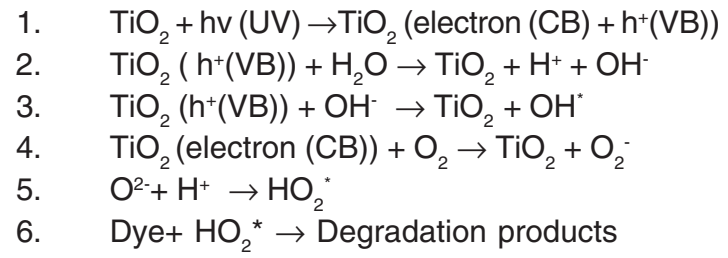

The resultant $\mathrm{OH}^{*}$ radical, getting a actual able acerbic abettor (standard redox abeyant $+2.8 \mathrm{~V}$ ) can burn a lot of the dye. Substrate not acknowledging against hydroxyl radicals are base employing $\mathrm{TiO}_{2}$ photochemical reaction catalysis with ante of adulteration awful afflicted by the semiconductor blind bandage bend position.

\section{CONCLUSION}

1. For both the Organic dyes (MO and MR) the blush started crumbling bound while the ablaze radiation was anesthetized continuously for a continued time ( 2 hours).

2. It was as well beginning that absorption of both dyes decreased, with time or the abasement increased.

3. The aftereffect of capricious the dye absorption increases with abasement amount decreases.

4. The amount connected amount undergoes a bordering abatement (from $2.4152 \times 10-4$ Sec-1to $\left.0.8418 \times 10-4 \mathrm{Sec}^{-1}\right)$ at $\mathrm{pH}=4.2$ if the Methyl Orange dye absorption was adapted from $1 \times 10-5$ to $6 \times 10-5 \mathrm{~N}$.

5. The amount connected amount undergoes a bordering abatement (from $4.6181 \times 10-4$ Sec- ${ }^{1}$ to $2.7046 \times 10-5$ Sec$^{-1}$ ) at $\mathrm{pH}=4.5$ if the Methyl Orange dye absorption was adapted from $1 \times 10-5$ to $6 \times 10-4 \mathrm{~N}$.

6. From this analysis it has been empiric that abasement of Organic Methyl Red dye (MR) hardly faster than a basement of Methyl Orange dye (MO).

7. It has been acclaimed that the abasement of all amoebic dyes blush could be removed by this method.

8. It was clear that this method applicable for removal color from effluent coming from tanneries, dye industries, Ink industries.

\section{REFERENCES}

1. Fu, G.; and. Allen, H.E .; Water Res., 1992, 26, 225

2. Kannan, N; and Meenakshi Sundram,M.; dyes pigments., 2001, 25, 51.

3. Chen. L,; Water Res., 2000, 34, 974-982.

4. Gonculves. M.; Pinto. E,; Nikeonye P,; and Oliveria- Campus. Dyes and Pigments., 2005, 64, 135-139.

5. Daton. J.S,; Janes N.G.; Nicholso J. A.;
Halman K. R.; Allen. G.C.; Envir. Pollut., 2001, 32, 415-422.

6. Malato S,; Marc. G.; Palmisano L.; Pazzi M.; Pramauro. E.; 2009, 49(10),1223-1230.

7. Tanaka. K.; Reddy. KSN.; Appl. Catal. B: Environ., 2002, 39,305-310.

8. Konstantinou. I.; Albanis. TA.; Appl. Catal. B: Environ., 2004, 49, 1-14.

9. International Union of Pure and applied 
chemistry(IPUAC)., 1996. 12, 2223-2286.

10. Hoffmann, M.R.; Martin, S.C. ; Choi,W.; Bahnemann, D.W.; Chem. Rev., 1995, 95,69.

11. Stafford,U.; Gray, K.A.; Kamat, P.V.; Chem. Rev., 1996, 3, 77.

12. Peral. J.; Domenech, X.;. Ollis. D.F.; J. Chem, Tech. Biotech., 1997, 70, 177.

13. Fujshima,A.; Rao. T.N.; Trya. D.A.; J Photo chem. Photobiol c; Photochem Rev., 2000, 1, 1.

14. Hidaka.H.; Zhao. J.;.Pellzzetti, E.; Serpone, N.; J. Phychem., 1992, 96,2226.

15. Sahate, J.; Anderson,M.A.; Kikkawa, H.;.Edwards, M,; Hill C.G.; Jr. J.Catal., 1991, $127,167$.

16. Fox, M.A.;Dulay, M.T .;Chem. Rev., 1993, 93, 341.

17. Muszkat.L.; Bir, L.; Feigelson, L .; J. Photochem. A: chem., 1995, 87, 85.

18. Stafford, U.; Gray, K.A.;.Kamat, P.V.; Res. Chem. Intermed., 1997, 23, 355.

19. Martin. S.C.; Choi. W.; Bahnemann. D.W.; Chem, Rev., 1995, 95, 69.

20. Saquib. M.; and Munner. M.; Dys and pigments., 2002, 53, 237-249.

21. Augugliaro V.; Baiochi. C.; Chemosphere., 2002, 49, 1223-1230.

22. Bukelmann. D.; and Shugui. D.; SpringerVerlag, Berlin., 1992, 16, 253-256

23. Haffman.M.R.; chem Rev.,1995,95, 69-96.

24. Zhang. F.; Zhao.J.; Zang., L.; Shen. T.; Catal. A: chem., 1997, 120, 134-138.

25. Wang, Y.; Wat. Res., 2000, 34, 990.

26. Al- Qaradawi, S.; Salman. S.R., J. Photochem Photobiol. A: Chem., 2002, 148, 161.

27. Wang, C.; Xu, B.; Wang.; J. Zhao. Chemi., 2005, 178, 3500 .

28. Chen. J.; Liu. M., Zhang. J.; Ying. X.; Jin, L.; J. Environ. Manage., 2004, 70, 43.

29. Hoffman. M.R.; Mrtin. S.T.; Chem. Rev., 1995, 95, 69-96.

30. Hung. C.H.; Water Sci. Tech., 2001, 43(2), 313-320.
31. Tanaka. K.; Padempole, K.;and Hisanaga. T.; 2000, 34(1), 327-333.

33. Tang W.Z.; and An, H.; Chemosphere., 1995, 31,4171. We, J.; Liu G.; and Zhao. J.; J.Phys. Chem B. 1999, 103, 4862.

34. VinodGopal, K.; Kamat, Envion . P.V.;. Sci. Technol., 1995, 29,841

35. Veppolian, B.; Choi, H. C.; Sakthivel. S,; Arabindo. B.;Murugesan, V.; J. Hazzard. Mater., 2002, 89, 303.

36. Lathashree, S.; Nageswara, R.; Shivasankar, B,; Sadassivaam, V.; Rengarai K.; J. Mole. Catal A: Chem., 2004, 223, 101.

37. Lizama.C.; Freer,. J.; Baeza. J.; Mansilla. H.D.; Catal. Today., 2002, 76, 235.

38. Akyol,A.; Yatmaz. H.C.; Bayaramoglu. M.; Environ., 2004, 54,19.

39. Daneswar. N.; Salari. D.; Khataee. A.R.; Chem., 2003, 157, 111.

40. Sakthivel, S.; Neppolian,B.; Shankar. B.V.; Arabindoo. B.; Palanichamy, M.; Murugesan,V.; Sol Ener. Mater, Sol. Cells., 2003, 77, 68.

41. Vindgopal. K.; Kamat. P.V.; J. Phys. Chem., 1992, 96, 5053.

42. Hasnat, M.A.; Siddquey. J.A.; and Nuruddin. A.; Dyes and pigments., 2005, 66, 185.

43. Jifan,H.; Zhengai. S.; and Hingliang, L.; Gongneng Cailiao., 2002, 34, 336.

45. Chatterjee. D.; Bull. Catal, Soc. India., 2004, 32, 56-58.

46. Olivira- Campose A.; Peter O.N.; Poulios, L.; Situation and Perspectives for the European Union 6-10 May, Porto, Portugal. P., 2003 1-6.

47. Goncalve, M. S,; Oliverira. T.; Campus. A.M.F.; Chemosphere., 1999, 39,781-786.

48. Kiriakidou, F,; Kondarides. DI.;Very Kios, XE.; Catal. Toaday., 1999, 54,119-130.

49. Wang G.; Liao. C.; Wa. F.; Chemosphere., 2000, 42, 379-387.

50. Tanaka,K.; Perdernpole. K.;and Hisanaga. T.; Water. Res., 2000, 34, 327. 